\title{
Factors affecting nurses' work motivation level at a governmental hospital: A cross-sectional study
}

\author{
Reem A. Baljoon ${ }^{* 1,2}$, Hasnah Banjar ${ }^{3}$, Maram Banakhar ${ }^{3}$ \\ ${ }^{1}$ King Faisal Special Hospital \& Research Centre, Jeddah, Saudi Arabia \\ ${ }^{2}$ Science of Nursing Administration, King Abdulaziz University, Saudi Arabia \\ ${ }^{3}$ Nursing Administration, Faculty of Nursing, King Abdulaziz University, Saudi Arabia
}

Received: December 10, 2018

Accepted: May 4, 2019

Online Published: June 6, 2019

DOI: $10.5430 /$ jnep.v9n9p25

URL: https://doi.org/10.5430/jnep.v9n9p25

\begin{abstract}
Background and aim: Nurses are working in different healthcare organizations; each healthcare organization has different organizational resources. Therefore, factors affecting nurses' work motivation are varied among nurses. This study aimed to identify factors affecting nurses' work motivation levels at a governmental hospital in Saudi Arabia.

Methods: A cross-sectional design was conducted by recruiting registered nurses $(n=280)$ who worked for at least one year of experience. The survey was distributed among registered nurses working in one governmental hospital in the Kingdom of Saudi Arabia to assess nurses' work motivation level and to identify the affecting factors.

Results: This study showed that nurses' work motivation level is affected by several personal and organizational factors. A positive relationship was found between higher order need strength and shared values and nurses' work motivation (intrinsic and extrinsic). This study revealed that there is a positive relationship between pay, promotion, supervision, fringe benefits, contingent rewards, co-workers, nature of work, communication and working conditions and nurses' work motivation level.

Conclusions: There is a need to enhance and promote the motivational strategies within the current study setting by providing satisfactory remuneration, equitable benefits increase the chances of promotion and encourage supportive supervision. Additionally, there is a need to create healthy workplace environment that support co-workers relationship.
\end{abstract}

Key Words: Nurses' motivation, Work motivation level, Personal factors, Organisational factors

\section{INTRODUCTION}

Motivation is known as a drive that makes an individual to seek out or achieve satisfaction of a need. ${ }^{[1]}$ Moreover, motivation was defined as determining the needs of the employee, implementing proper strategies and as the force that energizes, guides, and maintains human behaviour. ${ }^{[2]}$ In the work context, motivation can be defined as "an individual's degree of willingness to exert and maintain an effort towards organizational goals". ${ }^{[3]}$ Motivation is categorized into in- trinsic motivation (IM) and extrinsic motivation (EM) ${ }^{[1]}$ The main difference between these two types is that the motivational state where IM is internally derived "derives from within the individual, inspiring him or her to be productive", while EM is externally derived "enhanced by the job environment or external rewards" to meet personal or organizational goals..$^{[1,4]}$

Nurses' work motivation level is affected by several factors. These factors can be personal such as individual priorities

*Correspondence: Reem A. Baljoon; Email: remacute@ hotmail.com; Address: King Faisal Special Hospital \& Research Centre, Jeddah 21499, Saudi Arabia.

Published by Sciedu Press 
which involved shared values with hospital and attainment of higher order needs that increase nurses' work motivation level. ${ }^{[5]}$ Although the orientation of nurses' motivation at work depends on their individual priorities, the strength and sustainability of both IM and EM depends on the shared values. ${ }^{[6-8]}$

Generally, nurses are more likely to be autonomously motivated, if their work allow them to accomplish satisfaction in their needs for competence (i.e. productivity, knowledge and skill use), autonomy (i.e. decision authority), and relatedness (i.e. belonging to a team, good relationships with others, respect and the trust of co-workers). Most motivations reported among nurses were satisfied derived from a sense of accomplishment followed by the desired to learn new things. It was found that nurses working in general care wards or in the middle of their career with the dominant personal value "Benevolence" and high experience rate, reported to be highly motivated in contrast to those with the dominant value "Hedonism", who used computers infrequently or with low to medium experience rate. ${ }^{[9]}$ Similarly, nurses with higher score of competence and humanity reported higher level of work motivation. ${ }^{[5,10,11]}$ Likewise, nurses who reported a higher level of shared values in their hospital and nurses who conveyed a higher level of identification with the long-termcare setting had higher levels of work motivation. ${ }^{[5,12]}$

Furthermore, work motivation is affected by internal psychological states which built on the person priority of values and needs drives from personal factors. ${ }^{[5,13,14]}$ However, three critical internal psychological states were found in the literature for IM incorporate experienced responsibility for work results, a knowledge of the actual results of the activities and experienced meaningfulness of the job. ${ }^{[15]}$ Job meaningfulness was one of the most important motivating factors among health service providers. ${ }^{[16]}$ Moreover, a positive relationship between job meaningfulness and work motivation level was found in several studies. ${ }^{[5,17,18]}$

In contrast to personal factors, nurses' work motivation is also affected by several organisational factors. Work engagement is positively associated with intrinsic work motivation and with extrinsic work motivation. ${ }^{[19]}$ While in a further study, nurses confirmed that positive environment and supportive supervision and management motivated them to stay at their hospital. ${ }^{[20,21]}$ Additionally, interpersonal relationships, social respect, communication, effective teamwork and feedback could promote motivation in several studies. ${ }^{[1,20,22-24]}$

In a more recent study, it was reported that having a clear job description, clearness in responsibilities and tasks were important motivating factors in both management and per- formance aspect. ${ }^{[16,25]}$ Furthermore, career development and learning opportunity, chance for continuing professional development and growth had the highest ability to inspire nurses in their profession. ${ }^{[20,23,26-28]}$ Moreover, appreciation and recognition from community as well as the recognition and appreciation of a good job carried out by nurses could be the main motivation factor. ${ }^{[22,29]}$ In addition, financial incentives were most important motivating factor that advance nurses' performance. ${ }^{[25,28,30]}$

Health care system in Saudi Arabia (SA) faces many challenges that may alter or compromise the quality of patient care such as shortage in nursing staff, high turnover, severe stress and burnout. ${ }^{[31]}$ Moreover, in the context of SA, nurses are working in different healthcare organizations, each healthcare organization has different organizational resources and working conditions and therefore the motivation level and factors affecting nurses' work motivation are varied among nurses in different healthcare organizations. Importantly, the government of SA has a new direction of providing a cost-effective healthcare services in 2030. Therefore, due to the vision of 2030 and the current economic changes that noticed within the kingdom of SA in 2017, this resulted in several limitations and changes within the hospitals' human resources and hospitals' budgets. Thus, nursing mangers are limited in delivering extra financial incentives that could motivate nurses to perform better. ${ }^{[17]}$ Furthermore, nurses' work motivation level is varied not only according to the working context of the healthcare organization; however, it is varied in the time of change. Thus, in this period of significantly financial restraint and global shortages of nurses, it is vital for health care managers and administrators to be aware of the factors that affect work motivation. ${ }^{[32]}$ Therefore, this study aimed to identify factors affecting nurses' work motivation levels at a governmental hospital in Saudi Arabia.

\section{MATERIALS AND METHODS}

\subsection{Study design}

A descriptive cross-sectional study design was conducted to identify the factors affecting nurses' work motivation level in a governmental hospital.

\subsection{Participants}

Quota sampling technique was used to recruit all registered nurses (RNs) who are working in the hospital with at least one year of experience. In each unit, the researcher met the department's manager and introduced the aim of the study, questionnaire and inclusion criteria. The list of names for nurses who worked for one year and more in all the units were provided to the researcher by the manager of each unit. Nurses in each unit were selected based on their schedule 
which include their names. Then the researcher handed questionnaires in closed envelop to nurses after coordinating with the department managers. All questionnaires were collected in closed envelops in the following day. The sample consisted of 280 registered nurses, 252 included staff nurses while 28 were nurses holding managerial positions of grade 9 and above.

\subsection{Setting}

The study was conducted in a non-profit healthcare organisation that is well known as a reputable and accredited health care organisation in Jeddah city at SA. This hospital is providing a tertiary care by serving local community with 500-beds capacity for many years and has grown to become one of the leading healthcare organisation in the Middle East. This hospital has some unique characteristics such as high bed capacity, different culture, staffing and specialties. Importantly, due to the limited financial budget in 2017, many nurses resigned from this hospital leading to high turnover rate. In this study setting, the data were collected in July 2017.

\subsection{Instrument}

The questionnaire used in this study composed of four sections: Section 1 included the sociodemographic information, which was developed by the researcher; Section 2: This is pertaining toward assessing the nurses' work motivation level by using The Motivation at Work Scale (MAWS) ${ }^{[33]}$ MAWS was validated in many languages and consist of 12 statements measuring four variables which are: Intrinsic motivation, Identified regulation of extrinsic motivation, Introjected regulation of extrinsic motivation and External regulation of extrinsic motivation. MAWS used a seven-point likert scale, ranging from 1 "Not at all for this reason" to 7 "Exactly for this reason". The items scored on likert scale, with scores ranging from very low (1) to very high (7). Based on the range of possible mean scores distribution of scores from the instrument was as follows: Low motivation level (1-3.58), Moderate motivation level (3.59-4.43), High motivation level (4.44-7); Section 3: This section is aimed to assess nurses' personal factors which consists of two different parts. First part is Higher Order Need Strength Scale. ${ }^{[34]}$ This scale measuring nurses' higher order need strength such as a stronger need for achievement and self-actualization. This tool consists of 6 statements, accompanied a seven-point likert scale ranging from 1 "not at all important" to 7 "extremely important". Second part is Shared Values Scale ${ }^{[35]}$ which consists of 5 statements. This is Likert scale ranging from 1 "disagree strongly" to 7 "agree strongly". This scale is measuring the degree to which nurses sharing the same values with the organization; Section 4 aimed to assess organizational factors affecting nurses' work motivation level which consists of two different parts. First part is Job Satisfaction Survey $(\mathrm{JSS})^{[36]}$ to measure motivational factors "organizational factors". JSS consists of 36 statements with 9 facets (each facet with 4 items) are Pay, Promotion Supervision, Fringe Benefits, Contingent Rewards, Operating Procedures, Coworkers, Nature of Work, and Communication. A summated rating scale format is used, with six choices per item ranging from 1 "disagree very much" to 6 "agree very much". Second part is measuring working condition. ${ }^{[35]}$ It consists of four questions, which are working overtime hours and working for other people are (multiple choice questions), working schedule (forced choice), and opportunities for flexible work time (multiple choices).

The content validity of the tool was confirmed by a jury opinion that was taken by 5 experts from the faculty members at one university in Jeddah city and the fields of leadership and management in the current hospital. Written permission was taken from the original authors to use the questionnaires. Internal consistency of the scales was assessed by Cronbach's Alpha coefficient and found to be adequate: 0.882 for Motivation at Work Scale (MAWS), 0.868 for Higher Order Need Strength Scale, 0.873 for Shared Values Scale, 0.841 for JSS and 0.908 for the whole scale.

Ethical approval was obtained from the Ethics committee from the study setting. The study has no harm on the study sample. The study sample were permitted to withdraw from the study at any time. In addition, a cover page was created and attached to the questionnaire which incorporates an introduction about the purpose of the study, how and why the study sample were involved in the study, how long the questionnaire would take to be completed and the intended use of the results. Additionally, study sample were assured about information confidentiality.

\subsection{Data analysis}

A descriptive analysis was used to analyze the data of this study using SPSS (Statistical Package for the Social Sciences program) software version 20. Descriptive statistics were used for all data including frequency distributions and cross-tabulations. Spearman's rank correlation calculated for testing the relationships between continuous variables.

\section{Results}

\subsection{Sociodemographic characteristics of nurses}

The results of sociodemographic characteristics of nurses is presented in Table 1. 
Table 1. Frequency distribution of the registered nurses regarding sociodemographic variables $(\mathrm{n}=280)$

\begin{tabular}{|c|c|c|c|}
\hline \multirow{2}{*}{ Sociodemographic } & \multirow{2}{*}{ Classes of Variables } & \multicolumn{2}{|c|}{$n=280$} \\
\hline & & $\mathbf{N}$ & $\%$ \\
\hline \multirow{4}{*}{ Age } & Less than 25 years & 4 & 1.4 \\
\hline & $26-<35$ years & 128 & 45.7 \\
\hline & $35-<45$ years & 84 & 30.0 \\
\hline & 45 and above & 64 & 22.9 \\
\hline \multirow{2}{*}{ Gender } & Male & 15 & 5.4 \\
\hline & Female & 265 & 94.6 \\
\hline \multirow{4}{*}{ Marital status } & Single & 93 & 33.2 \\
\hline & Married & 181 & 64.7 \\
\hline & Divorced & 4 & 1.4 \\
\hline & Widow & 2 & 0.7 \\
\hline \multirow{2}{*}{ Nationality } & Saudi & 47 & 16.8 \\
\hline & Non-Saudi & 233 & 83.2 \\
\hline \multirow{5}{*}{ Educational level } & Diploma & 82 & 29.3 \\
\hline & Baccalaureate & 170 & 60.6 \\
\hline & Masters & 17 & 6.1 \\
\hline & PHD, DNP or other terminal degree & 1 & 0.4 \\
\hline & Others & 10 & 3.6 \\
\hline \multirow{4}{*}{ Years of experience } & Less than 5 & 11 & 3.9 \\
\hline & $(5-<10)$ & 78 & 27.9 \\
\hline & $(10-<20)$ & 116 & 41.4 \\
\hline & 20 and more & 75 & 26.8 \\
\hline \multirow{6}{*}{ Working period at (KFSH\& RC, J) } & Less than 1 year & 5 & 1.8 \\
\hline & $1-5$ years & 114 & 40.7 \\
\hline & $6-10$ years & 73 & 26.1 \\
\hline & 11-15 years & 61 & 21.8 \\
\hline & $16-20$ years & 25 & 8.9 \\
\hline & 21 years or more & 2 & 0.7 \\
\hline \multirow{2}{*}{ Position title or grade } & Staff Nurse & 252 & 90.0 \\
\hline & Grade 9 and above & 28 & 10.0 \\
\hline
\end{tabular}

A total of 280 registered nurses completed the questionnaires. nurses who participated in this study were represented from Less than half of nurses were between $26-<35$ years of age $(\mathrm{n}=128,45.7)$. In regard to the nationality, non-Saudi nurses were more than three quarters $(83.2 \%)$. The education level of the respondents showed that almost two thirds $(60.6 \%)$ had baccalaureate degree. More than two thirds $(68.2 \%)$ of the respondents had 10 and above years of experience. The results revealed that less than half (42.5\%) of nurses had 1-5 $\quad \mathbf{3 . 2}$ Work motivation level years of employment at the current hospital. Furthermore, The results of work motivation level is presented in Table 2.

Table 2. Nurses work motivation $(n=280)$

\begin{tabular}{|c|c|c|c|c|c|}
\hline \multicolumn{2}{|l|}{ Motivation } & Items & Weighted Mean & SD & Motivation level \\
\hline \multicolumn{2}{|c|}{ Total of Intrinsic work motivation } & 3 & 4.64 & 1.10 & High \\
\hline \multicolumn{2}{|c|}{ Total of Extrinsic work motivation } & 9 & 4.54 & 0.94 & High \\
\hline \multirow{3}{*}{$\begin{array}{l}\text { Subcategories of } \\
\text { Extrinsic work } \\
\text { motivation }\end{array}$} & Identified regulation of extrinsic work motivation & 3 & 5.00 & 1.12 & High \\
\hline & Introjected regulation of extrinsic work motivation & 3 & 4.51 & 1.34 & High \\
\hline & External regulation of extrinsic work motivation & 3 & 4.10 & 1.06 & Moderate \\
\hline
\end{tabular}


The total weighted mean for extrinsic work motivation (4.54 $\pm 0.94)$ was lower than intrinsic work motivation $(4.64 \pm$ 1.10). Nurses' work motivation level was moderate in external regulation of extrinsic work motivation $(4.10 \pm 1.06)$ but high in both intrinsic work motivation (4.64 \pm 1.10$)$ and in two subcategories of extrinsic work motivation namely identified regulation $(5 \pm 1.12)$ and introjected regulation $(4.51 \pm 1.34)$.

\subsection{Personal factors}

\subsubsection{Higher order need strength}

The results of work motivation level is presented in Table 3.

Table 3. The weighted means, standard deviations and overall nurses' responses of higher order need strength

\begin{tabular}{llll}
\hline Items of Higher Order Need Strength & Weighted Mean & SD & Overall Response \\
\hline Using your skills to the maximum. & 6.24 & 1.11 & Extremely important \\
Achieving something that you personally value. & 6.11 & 1.03 & Fairly important \\
The opportunity to make your own decisions. & 5.95 & 1.06 & Fairly important \\
The opportunity to learn new things. & 6.25 & 1.01 & Extremely important \\
Challenging work. & 6.08 & 1.01 & Fairly important \\
Extending your range of abilities. & 6.09 & 1.05 & Fairly important \\
Total & 5.67 & 0.74 & Fairly important \\
\hline
\end{tabular}

The total weighted mean of higher order need strength $(5.67$ \pm 0.74 ) which indicated as "fairly important" need to the nurses. Moreover, the highest weighted mean reported by nurses was $6.25 \pm 1.01$ for "the opportunity to learn new things" followed by $6.24 \pm 1.11$ to the statement "using skills to the maximum" which both indicated as "extremely important" needs to nurses. However, the lowest weighted mean was $5.95 \pm 1.06$ for "the opportunity to make your own decisions" which indicated "fairly important" need.

\subsubsection{Shared values}

The results of shared values is presented in Table 4.

Table 4. The weighted means, standard deviations and overall nurses' responses of shared values

\begin{tabular}{llll}
\hline Items of shared values & Weighted mean & SD & Overall response \\
\hline $\begin{array}{l}\text { I share the values and believes of this hospital. } \\
\text { Managers here are understanding about employees having to meet } \\
\text { family responsibilities. }\end{array}$ & 5.56 & 1.29 & Agree moderately \\
People working here are encouraged to develop themselves. & 5.33 & 1.49 & Agree moderately \\
I am proud to tell people what specialty or profession I'm working in. & 5.99 & 1.39 & Agree moderately \\
I am proud to tell people what institution I'm working at. & 6.09 & 1.26 & Agree moderately \\
Total & 5.67 & 1.18 & Agree moderately \\
\hline
\end{tabular}

The total weighted mean of nurses' shared value (5.67 \pm 1.08). Nurses "agreed moderately" to the statement "I am proud to tell people what institution I'm working at" with highest weighed mean $(6.09 \pm 1.18)$. Whereas, the lowest weighted mean $(5.33 \pm 1.49)$ was reported by nurses who "agreed moderately" to the statement "Managers here are understanding about employees having to meet family responsibilities".

\subsection{Organizational factors}

\subsubsection{Sub-factors of job satisfaction survey (JSS)}

The results of organizational factors is presented in Table 5.

Nurses 'agreed moderately' that supervision and nature of work can motivate them to work with the total weighted mean (4.78 \pm 0.94$) ;(4.53 \pm 0.85)$ respectively. Whereas nurses 'agreed slightly' that communication and contingent rewards can motivate them to work with the total weighted mean $(4.28 \pm 0.91),(3.52 \pm 0.95)$. However, nurses 'disagreed slightly' that the pay and promotion can motivate them to work with a total weighted mean of (3.14 \pm 0.97$),(3.38 \pm$ 0.86 ) respectively. Moreover, nurses 'disagreed slightly' that operating conditions and fringe benefits can motivate nurses to work with the total weighted mean $(2.99 \pm 0.70),(2.89 \pm$ $0.91)$.

\subsubsection{Working conditions}

The results of working conditions is illustrated in Table 6. 
Table 5. The weighted means, standard deviations and overall responses of nurses in JSS $(n=280)$

\begin{tabular}{|c|c|c|c|c|}
\hline & Items & Mean & SD & Overall response \\
\hline \multirow{5}{*}{ Pay } & 1- I feel I am being paid a fair amount for the work I do. & 3.26 & 1.61 & Disagree slightly \\
\hline & 10- Raises are too few and far between. & 2.86 & 1.26 & Disagree slightly \\
\hline & 19- I feel unappreciated by the organization when I think about what they pay me. & 3.36 & 1.47 & Disagree slightly \\
\hline & 28- I feel satisfied with my chances for salary increases. & 3.08 & 1.75 & Disagree slightly \\
\hline & Total & 3.14 & 0.97 & Disagree slightly \\
\hline \multirow{5}{*}{ Promotion } & 2- There is really too little chance for promotion on my job. & 3.04 & 1.47 & Disagree slightly \\
\hline & 11- Those who do well on the job stand a fair chance of being promoted. & 3.74 & 1.41 & Agree slightly \\
\hline & 20- People get ahead as fast here as they do in other places. & 3.41 & 1.25 & Disagree slightly \\
\hline & 33- I am satisfied with my chances for promotion. & 3.34 & 1.44 & Disagree slightly \\
\hline & Total & 3.38 & 0.86 & Disagree slightly \\
\hline \multirow{5}{*}{ Supervision } & 3- My supervisor is quite competent in doing his/her job. & 4.78 & 1.20 & Agree moderately \\
\hline & 12- My supervisor is unfair to me. & 4.99 & 1.29 & Agree moderately \\
\hline & 21- My supervisor shows too little interest in the feelings of subordinates. & 4.48 & 1.41 & Agree moderately \\
\hline & 30- I like my supervisor. & 4.88 & 1.15 & Agree moderately \\
\hline & Total & 4.78 & 0.94 & Agree moderately \\
\hline \multirow{5}{*}{$\begin{array}{l}\text { Fringe } \\
\text { Benefits }\end{array}$} & 4- I am not satisfied with the benefits I receive. & 3.08 & 1.54 & Disagree slightly \\
\hline & 13- The benefits we receive are as good as most other organizations offer. & 2.91 & 1.43 & Disagree slightly \\
\hline & 22- The benefit package we have is equitable. & 3.18 & 1.34 & Disagree slightly \\
\hline & 29- There are benefits we do not have which we should have. & 2.38 & 1.55 & Disagree moderately \\
\hline & Total & 2.89 & 0.91 & Disagree slightly \\
\hline \multirow{5}{*}{$\begin{array}{l}\text { Contingent } \\
\text { rewards }\end{array}$} & 5- When I do a good job, I receive the recognition for it that I should receive. & 3.90 & 1.48 & Agree slightly \\
\hline & 14- I do not feel that the work I do is appreciated. & 3.79 & 1.47 & Agree slightly \\
\hline & 23- There are few rewards for those who work here. & 3.19 & 1.26 & Disagree slightly \\
\hline & 32- I don't feel my efforts are rewarded the way they should be. & 3.21 & 1.40 & Disagree slightly \\
\hline & Total & 3.52 & 0.95 & Agree slightly \\
\hline \multirow{5}{*}{$\begin{array}{l}\text { Operating } \\
\text { conditions }\end{array}$} & 6- Many of our rules and procedures make doing a good job difficult. & 3.03 & 1.24 & Disagree slightly \\
\hline & 15- My efforts to do a good job are seldom blocked by red tape. & 3.16 & 1.35 & Disagree slightly \\
\hline & 24- I have too much to do at work. & 2.87 & 1.32 & Disagree slightly \\
\hline & 31- I have too much paperwork and documentation. & 2.90 & 1.54 & Disagree slightly \\
\hline & Total & 2.99 & 0.70 & Disagree slightly \\
\hline \multirow{5}{*}{ Coworkers } & 7- I like the people I work with. & 4.85 & 1.04 & Agree moderately \\
\hline & 16- I find I have to work harder at my job because of the incompetence of people I work with. & 4.13 & 1.42 & Agree slightly \\
\hline & 25- I enjoy my coworkers. & 4.67 & 1.15 & Agree moderately \\
\hline & 34- There is too much fighting at work. & 4.11 & 1.52 & Agree slightly \\
\hline & Total & 4.44 & 0.94 & Agree moderately \\
\hline \multirow{5}{*}{$\begin{array}{l}\text { Nature of } \\
\text { work }\end{array}$} & 8- I sometimes feel my job is meaningless. & 4.26 & 1.48 & Agree slightly \\
\hline & 17- I like doing the things I do at work. & 4.71 & 1.09 & Agree moderately \\
\hline & 27- I feel a sense of pride in doing my job. & 4.74 & 1.06 & Agree moderately \\
\hline & 35- My job is enjoyable. & 4.40 & 1.22 & Agree moderately \\
\hline & Total & 4.53 & 0.85 & Agree moderately \\
\hline \multirow{5}{*}{$\begin{array}{l}\text { Communi- } \\
\text { cation }\end{array}$} & 9- Communications seem good within this organization. & 4.26 & 1.18 & Agree slightly \\
\hline & 18- The goals of this organization are not clear to me. & 4.79 & 1.31 & Agree moderately \\
\hline & 26- I often feel that I do not know what is going on with the organization. & 3.78 & 1.37 & Agree slightly \\
\hline & 36- Work assignments are not fully explained. & 4.27 & 1.51 & Agree slightly \\
\hline & Total & 4.28 & 0.91 & Agree slightly \\
\hline
\end{tabular}

The results of working conditions is illustrated in Table 6. for other reasons in addition to their own work. RegardHalf of nurses $(52.5 \%)$ had overtime in their hospital. In ing participants' schedule, two third of nurses (61.1\%) were terms of working for others, half of nurses $(55.7 \%)$ were rotating between day and night shifts and almost one third seldom working for their colleagues who are ill or absent $(28.9 \%)$ had fixed schedule (day work with regular working 
hours). In addition, the most three opportunities needed by nurses were "flexible working hour", followed by "change shift with other", and "plan your working schedule by your own" respectively $46.4 \%, 28.9 \%$ and $28.6 \%$.

\subsection{Correlations between nurses' work motivation and} (personal \& organizational) factors

Correlations between nurses' work motivation and personal and organizational factors is found in Table 7.

Table 6. Frequency and relative frequency distribution of the sample according to working conditions variables

\begin{tabular}{|c|c|c|c|}
\hline \multirow{2}{*}{ Working conditions instrument } & \multirow{2}{*}{ Classes of Variables } & \multicolumn{2}{|c|}{$\mathrm{n}=\mathbf{2 8 0}$} \\
\hline & & f & $\%$ \\
\hline \multirow{2}{*}{$\begin{array}{l}\text { Do you work overtime in your } \\
\text { hospital? }\end{array}$} & Yes & 147 & 52.5 \\
\hline & No & 133 & 47.5 \\
\hline \multirow{5}{*}{$\begin{array}{l}\text { How often do you have to do the } \\
\text { work of colleagues who are ill or } \\
\text { absent for other reasons in } \\
\text { addition to your own regular } \\
\text { work? }\end{array}$} & Never & 31 & 11.1 \\
\hline & Seldom & 156 & 55.7 \\
\hline & Quite often & 64 & 22.9 \\
\hline & Very often & 18 & 6.4 \\
\hline & Does not apply & 11 & 3.9 \\
\hline \multirow{5}{*}{$\begin{array}{l}\text { What kind of working schedule do } \\
\text { you have in your current position? }\end{array}$} & Day work with regular working hours (fixed schedule) & 81 & 28.9 \\
\hline & Shift work without nights & 20 & 7.1 \\
\hline & Rotating day and nights shifts & 171 & 61.1 \\
\hline & Only night shifts & 4 & 1.4 \\
\hline & Other & 4 & 1.4 \\
\hline \multirow{8}{*}{$\begin{array}{l}\text { Needing any of these } \\
\text { opportunities }\end{array}$} & 1- Flexible working hour & 130 & 46.4 \\
\hline & 2- Nursery at work-place or the compensation of it & 50 & 17.9 \\
\hline & 3- Share the workload or shift to some-one else & 58 & 20.7 \\
\hline & 4- Work at or from home in normal working hours & 27 & 9.6 \\
\hline & 5- Change your shift with someone else & 81 & 28.9 \\
\hline & 6- Plan your working schedule on your own (pick suitable date, time etc.) & 80 & 28.6 \\
\hline & 7- Parental leave & 66 & 23.6 \\
\hline & 8- None of these & 68 & 24.3 \\
\hline
\end{tabular}

\section{Discussion}

\subsection{Personal factors affecting nurses' work motivation}

The current study demonstrated that the attainment of higher order needs was positively correlated with IM and all types of EM. This result is in line with a study which suggested that attainment of higher order needs increased both IM and EM level of hospital nurses. ${ }^{[5]}$ This can be explained by the notion that nurses at the current hospital had the need for achievement, growth and self-actualization (higher order needs), while the stronger need was for material and social benefits (lower order need).

In the context of higher order needs, nurses in the current study highlighted that opportunity to learn new things and the maximum use of skills were the highest needs. This result is in agreement with another study suggested that most motivations common among nurses were satisfied derived from a sense of accomplishment followed by the desired to learn new things. ${ }^{[9]}$ Nursing and technology advances move fast. Thus, new nurses require advanced knowledge and experience at work to be more familiar with new technology.

The results of the present study revealed that shared values were positively correlated with nurses' work motivation (with both IM and EM). This result is supported in the literature which indicated that shared values is positively associated with IM and with two types of EM namely identified regulation and external regulation. ${ }^{[35,37]}$ Nurses at the current hospital had more shared values with their organization and therefore were more autonomously and intrinsically motivated. A possible explanation for this is that if the nurses' values of and their organization are compatible the values will be internalized. Consequently, nurses will have more self-direction and their work become more meaningful and personally important.

\subsection{Organisational factors and extrinsic work motiva- tion}

This study found that there is a positive relationship between promotion and EM (identified regulation and external regu- 
lation). This outcome is corresponding to previous studies that found the promotion as a predictors of health worker motivation. ${ }^{[27,37-39]}$ The positive relationship between promotion and EM can be explained by the fact that giving the opportunity for promotion within the hospital will allow the nurse to achieve life's goal through the work involvement and organizational commitment. Additionally, opportunities for promotion can give the nurse a sense of value leading to increase the motivation level. Furthermore, new or high responsibilities with the new promoted job can fulfils nurses' career plan. In addition to this, when the nurse is promoted within the hospital this lead to an increase within the salary and therefore nurses can be motivated by having an allowance and have a good standard of living.

Table 7. The correlations between work motivation and personal and organizational factors $(\mathrm{n}=280)$

\begin{tabular}{|c|c|c|c|c|c|}
\hline $\begin{array}{ll} & \text { Work Motivation } \\
\text { Factors } & \end{array}$ & The test & $\begin{array}{l}\text { Intrinsic work } \\
\text { motivation }\end{array}$ & $\begin{array}{l}\text { Identified } \\
\text { regulation }\end{array}$ & $\begin{array}{l}\text { Introjected } \\
\text { regulation }\end{array}$ & $\begin{array}{l}\text { External } \\
\text { regulation }\end{array}$ \\
\hline \multicolumn{6}{|l|}{ Personal factors } \\
\hline \multirow{2}{*}{ Higher order need strength } & Spearman & $0.310 * *$ & $0.294 * *$ & $0.287 * *$ & $0.373^{* *}$ \\
\hline & ( $p$-value) & .000 & .000 & .000 & .000 \\
\hline \multirow{2}{*}{ Shared values } & Spearman & $0.425 * *$ & $0.404 * *$ & $0.395^{* *}$ & $0.253^{* *}$ \\
\hline & ( $p$-value) & .000 & .000 & .000 & .000 \\
\hline \multicolumn{6}{|l|}{ Organizational factors } \\
\hline \multirow{2}{*}{ Pay } & Spearman & $0.218^{* *}$ & $0.170^{* *}$ & $0.183 * *$ & $0.192 * *$ \\
\hline & ( $p$-value) & .000 & .004 & .002 & .001 \\
\hline \multirow{2}{*}{ Promotion } & Spearman & 0.086 & $0.132 *$ & 0.110 & $0.137^{*}$ \\
\hline & (p-value) & .149 & .028 & .066 & .022 \\
\hline \multirow{2}{*}{ Supervision } & Spearman & $0.197 * *$ & $0.207 * *$ & $0.192 * *$ & 0.055 \\
\hline & ( $p$-value) & .001 & .001 & .001 & .359 \\
\hline \multirow{2}{*}{ Fringe Benefits } & Spearman & $0.143^{*}$ & $0.124 *$ & 0.100 & 0.048 \\
\hline & (p-value) & .017 & .038 & .097 & .425 \\
\hline \multirow{2}{*}{ Contingent rewards } & Spearman & $0.221 * *$ & $0.219 * *$ & $0.207^{* *}$ & 0.105 \\
\hline & (p-value) & .000 & .000 & .000 & .078 \\
\hline \multirow{2}{*}{ Operating conditions } & Spearman & 0.070 & 0.010 & 0.089 & 0.002 \\
\hline & ( $p$-value) & .241 & .871 & .138 & .974 \\
\hline \multirow{2}{*}{ Coworkers } & Spearman & $0.205^{* *}$ & $0.225^{* *}$ & $0.171^{* *}$ & 0.042 \\
\hline & (p-value) & .001 & .000 & .004 & .481 \\
\hline \multirow{2}{*}{ Nature of work } & Spearman & $0.538 * *$ & $0.400 * *$ & $0.333 * *$ & 0.098 \\
\hline & (p-value) & .000 & .000 & .000 & .103 \\
\hline \multirow{2}{*}{ Communication } & Spearman & $0.174 * *$ & $0.205^{* *}$ & $0.193 * *$ & 0.070 \\
\hline & ( $p$-value) & .003 & .001 & .001 & .246 \\
\hline
\end{tabular}

${ }^{*} p<.05 ;{ }^{* *} p<.01$

\subsection{Organisational factors and intrinsic and extrinsic work motivation}

This study demonstrated that there is a positive relationship between pay and IM and all types of EM. This finding is compatible to previous studies suggested that salary increase is important motivating factor could promote nurses' work motivation level. ${ }^{[20,22,24,28,30,40-42]}$ This can be explained by the fact that income and financial allowance is important motivators which able to fulfil various individual needs. Moreover, receiving a good salary for all nurses can result in feeling of enjoyment and pleasure in doing the work.
Regarding the supervision in this hospital, this study demonstrated that there was a positive relationship between supervision and IM and EM. This outcome is corresponding to previous study which found that supervision is associated with healthcare workers' motivation. ${ }^{[43,44]}$ Similarly, supervisors' support was found to be important motivating factors in several studies. ${ }^{[11,16,20]}$ Supportive supervision can create a healthy work environment as nurses can feel the sense of pleasure and fun in their job as well as assist them to meet their personal values.

Considering the contingent rewards, this study demonstrated 
that there is a positive relationship between contingent rewards (as recognition, appreciation and rewards) and IM and EM. Comparing the current result, it was suggested that rewards and nurses' work motivation are directly and positively associated. ${ }^{[46]}$ This finding is consistent with several studies found contingent rewards as motivating factors which can increase nurses' work motivation level. ${ }^{[20,26,28,42]}$ The fact that being recognized and appreciated is a validation of the nurse competence and therefore this can motivate nurses to work.

Regarding the co-workers, this study revealed a positive relationship between co-workers and IM and EM. This finding is compatible with several studies which found that nurses can be motivated with their co-workers as effective team work is considered as important motivating factors in the healthcare organization. ${ }^{[11,22,47]}$ In addition, functional teamwork increased intrinsic work motivation only. ${ }^{[35]}$ Good relationship between coworkers enhance work to be more fun and fit nurses' values. Moreover, high competition between nurses can motivate them to work hard to avoid failure and blame and increase their chance to success.

With regards to communication, the current study revealed a positive relationship between communication and IM and EM. This finding is consistent with previous studies suggested that supportive relationship in the workplace (between team members) that valued effective communication and feedback was found to be linked with an increase of nurses' work motivation. ${ }^{[17,19,22,45]}$ Similarly, effective communication in the organization increased the health workers motivation. ${ }^{[38]}$ Therefore, effective communication between team members make the job enjoyable and fun as well as allow nurses to reach their goals and be a winner which will increase work motivation level. Additionally, the results that communication associated with introjected regulation indicates a certain external pressure as there are many nurses who communicate well not because they have an inner interest, but rather because they are afraid from failure and losing the respect of individuals who have placed a lot of expectations on them.

The current study was conducted in one governmental hospital in SA, and therefore it is difficult to generalize the results of the current study as SA is characterized by having different healthcare systems and therefore different work contexts. In addition, finding and selecting appropriate instrument for measuring all the organizational factors that are related to nurses' work motivation was very challenging in designing this study due to the in-depth search in the database and consultations with several academic staff in this domain. This was resulted in using two previously used scales were $\mathrm{JSS}^{[36]}$ and working condition scale. ${ }^{[35]}$ Unlike other tools about work in general, these were considered to describe uniquely nurses' common working conditions and work-place features in the actual context of their professional work.

\section{Conclusion}

This study found that pay is an important factor affecting all types of nurses' work motivation. Furthermore, among all the correlations between work motivation and organizational factors, the highest correlation was found between nature of work and each of intrinsic work motivation followed by identified regulation then introjected regulation of extrinsic work motivation. However, no correlation was found between operating conditions (including rules and procedure and work overload) and all types of work motivation. The results of this study are difficult to be generalized as this study was conducted in one governmental hospital in SA.

There is a need for enhancing motivation strategies by providing satisfactory remuneration for nurses as insufficient amount of payment and allowances would lead to low level of work motivation. Increase the chances of promotion for nurses in the current hospital by increasing the number of the new positions as required such as having nurse educators' positions within the units that need this service. Encourage supportive supervision by paying more consideration and interest to the feeling of staff as well as to be fair in treating all the staff in a similar way within the organization to promote positive managerial practices and create motivation strategies that focus on justice, positive environment to increase motivation level among nurses. Increase the chance for the nurses to have flexible working hours, such as part time opportunity to nurses which assist them to achieve better work life balance and increase work motivation level. Providing flexible policy that allow nurses to change shift with other when possible and allow them to plan their working schedule by their own such as pick the appropriate time and date. Assess nurses' work motivation level by surveying nurses frequently. Moreover, a qualitative research is required to explore how and why personal and organizational factors affecting nurses' work motivation by using interviews and focus groups for more in-depth exploration and explanation regarding nurses' work motivation. Furthermore, a further study is needed to examine the impact of nurses' motivation at work and patients' outcomes.

\section{ACKNOWLEDGEMENTS}

Special thanks to my family members in particular my parents, husband and kids for their continuous support and encouragement. Also, I would like to offer my sincere thanks 


\section{and appreciation to M Gagne, P Warr, K Toode and PE Spec- CONFLICTS OF INTEREST DisCLOSURE}

tor who gave me the permission to conduct my research using The authors declare that there is no conflict of interest. their tools.

\section{REFERENCES}

[1] Ryan RM, Deci EL. Intrinsic and extrinsic motivations: Classic definitions and new directions. Contemporary Educational Psychology. 2000; 25(1): 54-67. PMid:10620381 https://doi.org/10.100 6/ceps. 1999.1020

[2] Heidarian AR, Kelarijani SE, Jamshidi R, et al. The relationship between demographic characteristics and motivational factors in the employees of social security hospitals in Mazandaran. Caspian Journal of Internal Medicine. 2015; 6(3): 170.

[3] Franco LM, Bennett S, Kanfer R. Health sector reform and public sector health worker motivation: a conceptual framework. Social Science \& Medicine. 2002; 54(8): 1255-1266. https : //doi .org/ 10.1016/S0277-9536(01)00094-6

[4] Marquis BL, Huston CJ. Leadership Rules and Management Functions in Nursing. Philadelphia: Wolters Kluwer Health/Lippincott Williams \& Wilkins; 2012.

[5] Toode K, Routasalo P, Helminen M, et al. Hospital nurses' individual priorities, internal psychological states and work motivation. International Nursing Review. 2014; 61(3): 361-370. PMid:25091088 https://doi.org/10.1111/inr.12122

[6] Battistelli A, Galletta M, Portoghese I, et al. Mindsets of commitment and motivation: Interrelationships and contribution to work outcomes. The Journal of Psychology. 2013; 147(1): 17-48. PMid:23472442 https://doi.org/10.1080/00223980.2012.668146

[7] Galletta M, Portoghese I, Battistelli A. Intrinsic motivation, job autonomy and turnover intention in the Italian healthcare: The mediating role of affective commitment. Journal of Management Research. 2011; 3(2): 1. https://doi.org/10.5296/jmr.v3i2.619

[8] Koch SH, Proynova R, Paech B, et al. The perfectly motivated nurse and the others: workplace and personal characteristics impact preference of nursing tasks. Journal of Nursing Management. 2014; 22(8): 1054-1064. PMid:24033771 https ://doi.org/10.1111/ jonm. 12083

[9] Gădălean I, Pop F, Cheptea M. Motivation and professional performance in nursing. Acta Medica Transilvanica. 2013; 18(3).

[10] Thu NTH, Wilson A, McDonald F. Motivation or demotivation of health workers providing maternal health services in rural areas in Vietnam: findings from a mixed-methods study. Human Resources for Health. 2015; 13(1): 91. PMid:26626015 https: //doi.org/10.1186/s12960-015-0092-5

[11] Bhatnagar A, Gupta S, Alonge O, et al. Primary health care workers' views of motivating factors at individual, community and organizational levels: a qualitative study from Nasarawa and Ondo states, Nigeria. The International Journal of Health Planning and Management. 2017; 32(2): 217-233. PMid:27062268 https ://doi .org/ 10.1002/hpm. 2342

[12] Van Beek AP, Wagner C, Frijters DH, et al. The ties that bind? Social networks of nursing staff and staff's behaviour towards residents with dementia. Social Networks. 2013; 35(3): 347-356. https://doi.org/10.1016/j.socnet.2013.03.006

[13] Ryan JC. Development of a measure of work motivation for a metatheory of motivation. Psychological Reports. 2011; 108(3): 743-755. PMid:21879620 https://doi.org/10.2466/01.14.20.PR0.1 $08.3 .743-755$
[14] Warr P. Jobs and job-holders: Two sources of happiness and unhappiness. The Oxford handbook of happiness. 2013; 733-750.

[15] Hackman JR. Work redesign and motivation. Professional Psychology. 1980; 11(3): 445. https://doi.org/10.1037/0735-7028. 11.3. 445

[16] Purohit B, Maneskar A, Saxena D. Developing a tool to assess motivation among health service providers working with public health system in India. Human Resources for Health. 2016; 14(1): 15 PMid:27080388 https://doi.org/10.1186/s12960-016-011 $1-1$

[17] Gaki E, Kontodimopoulos N, Niakas D. Investigating demographic, work-related and job satisfaction variables as predictors of motivation in Greek nurses. Journal of Nursing Management. 2013; 21(3): 483490. PMid:23409751 https://doi.org/10.1111/j.1365-283 4.2012.01413.x

[18] Ibeziako O, Chabikuli O, Olorunju S. Hospital reform and staff morale in South Africa: a case study of Dr Yusuf Dadoo Hospital. South African Family Practice. 2013; 55(2): 180-185. https : //doi.org/10.1080/20786204.2013.10874330

[19] Van Beek I, Hu Q, Schaufeli WB, et al. For fun, love, or money: What drives workaholic, engaged, and burned-out employees at work? Applied Psychology. 2012; 61(1): 30-55. https ://doi .org/10.111 $1 / j .1464-0597.2011 .00454 . x$

[20] Kamanzi J, Nkosi Z. Motivation levels among nurses working at Butare University teaching hospital, Rwanda. Africa Journal of Nursing and Midwifery. 2011; 13(2): 119-131.

[21] Zinnen V, Paul E, Mwisongo A, et al. Motivation of human resources for health: a case study at rural district level in Tanzania. The International Journal of Health Planning and Management. 2012; 27(4): 327 347. PMid:22714251 https://doi.org/10.1002/hpm. 2117

[22] Jaiswal P, Singhal AK, Gadpayle AK, et al. Level of motivation amongst health personnel working in a tertiary care government hospital of New Delhi, India. Indian Journal of Community Medicine: Official Publication of Indian Association of Preventive \& Social Medicine. 2014; 39(4): 235. PMid:25364148 https : //doi.org/10.4103/0970-0218.143027

[23] Zarei E, Najafi M, Rajaee R, et al. Determinants of job motivation among frontline employees at hospitals in Tehran. Electronic Physician. 2016; 8(4): 2249. PMid:27280000 https ://doi .org/10.1 $9082 / 2249$

[24] Said RM, Abed FA, Abdo LM. Work Motivating Factors as Identifed by Nurses in Children Hospital at Elmonira and Specialized Pediatric Hospital Cairo University. The Medical Journal of Cairo University. 2013; 81(2).

[25] Sato M, Maufi D, Mwingira UJ, et al. Measuring three aspects of motivation among health workers at primary level health facilities in rural Tanzania. PloS One. 2017; 12(5): e0176973. PMid:28475644 https://doi.org/10.1371/journal.pone.0176973

[26] Negarandeh R, Dehghan-Nayeri N, Ghasemi E. Motivating factors among Iranian nurses. Iranian Journal of Nursing and Midwifery Research. 2015; 20(4): 436. PMid:26257797 https ://doi .org/ 10.4103/1735-9066.161011

[27] Adzei FA, Atinga RA. Motivation and retention of health workers in Ghana's district hospitals: addressing the critical issues. Journal 
of Health Organization and Management. 2012; 26(4): 467-485. PMid:23115900 https://doi.org/10.1108/14777261211251 535

[28] Dar S, Zehra N, Ahmad F. Extrinsic factors strong motivators for nurses in tertiary care hospitals. Pak J Med Dent. 2014; 3(1): 31-36.

[29] Prytherch H, Kakoko D, Leshabari M, et al. Maternal and newborn healthcare providers in rural Tanzania: in-depth interviews exploring influences on motivation, performance and job satisfaction. Rural Remote Health. 2012; 12(3).

[30] Negussie N. Relationship between rewards and nurses' work motivation in Addis Ababa hospitals. Ethiopian Journal of Health Sciences. 2012; 22(2).

[31] Al-Turki HA, Al-Turki RA, Al-Dardas HA, et al. Burnout syndrome among multinational nurses working in Saudi Arabia. Annals of African Medicine. 2010; 9(4). PMid:20935422 https: //doi.org/10.4103/1596-3519.70960

[32] Perreira TA, Innis J, Berta W. Work motivation in health care: a scoping literature review. International Journal of Evidence-based Healthcare. 2016; 14(4): 175-182. PMid:27552534 https://doi. org/10.1097/XEB. 0000000000000093

[33] Gagné M, Forest J, Gilbert MH, et al. The Motivation at Work Scale: Validation evidence in two languages. Educational and Psychological Measurement. 2010; 70(4): 628-646. https://doi.org/10.117 7/0013164409355698

[34] Warr P, Cook J, Wall T. Scales for the measurement of some work attitudes and aspects of psychological well-being. Journal of Occupational and Organizational Psychology. 1979; 52(2): 129-148. https://doi.org/10.1111/j.2044-8325.1979.tb00448.x

[35] Toode K. Nurses' work motivation: Essence and associations. Academic dissertation. University of Tampere. 2015. Available from: http://tampub.uta.fi/bitstream/handle/10024/9 6785/978-951-44-9746-9.pdf? sequence=1\&isAllowed=y

[36] Spector PE. Job satisfaction survey. In: Tempa: University of South Florida; 1994.

[37] Razee H, Whittaker M, Jayasuriya R, et al. Listening to the rural health workers in Papua New Guinea-the social factors that influence their motivation to work. Social Science \& Medicine. 2012; 75(5): 828-835. PMid:22632846 https ://doi.org/10.1016/j. socscimed.2012.04.013
[38] Weldegebriel Z, Ejigu Y, Weldegebreal F, et al. Motivation of health workers and associated factors in public hospitals of West Amhara, northwest ethiopia. Patient Preference and Adherence. 2016; 10: 159. PMid:26929608 https://doi.org/10.2147/PPA.S90323

[39] Ankomah SE, Kumah E, Karikari AK. Health Worker Motivation in Ghana: the role of non-financial incentives. A case study of Accident and Emergency Department of Komfo Anokye Teaching Hospital International Journal of Biosciences, Healthcare Technology and Management. 2016; 6: 34-49.

[40] Akbari J. The Study of Motivating Factors in the Nursing Staff of Shahid Ansari Hospital of Rudsar. International Journal of Humanities and Cultural Studies (IJHCS). 2016; 1(1): 1589-1597.

[41] Bonsdorff ME. Age-related differences in reward preferences. The International Journal of Human Resource Management. 2011; 22(06): 1262-1276. https://doi.org/10.1080/09585192.2011.5590 98

[42] Kantek F, Yildirim N, Kavla İ. Nurses' perceptions of motivational factors: a case study in a Turkish university hospital. Journal of Nursing Management. 2015; 23(5): 674-681. PMid:24372763 https://doi.org/10.1111/jonm. 12195

[43] Ojakaa D, Olango S, Jarvis J. Factors affecting motivation and retention of primary health care workers in three disparate regions in Kenya. Human Resources for Health. 2014; 12(1): 33. PMid:24906964 https://doi.org/10.1186/1478-4491-12-3 3

[44] Dagne T, Beyene W, Berhanu N. Motivation and factors affecting it among health professionals in the public hospitals, central Ethiopia. Ethiopian Journal of Health Sciences. 2015; 25(3): 231242. https://doi.org/10.4314/ejhs.v25i3.6

[45] Daneshkohan A, Zarei E, Mansouri T, et al. Factors affecting job motivation among health workers: a study from Iran. Global Journal of Health Science. 2015; 7(3): 153. https://doi.org/10.5539/ gjhs.v7n3p153

[46] Iranmanesh S, Fuladvand M, Ameri GF, et al. Iranian nurses' organizational commitment and job motivation. Asian Journal of Nursing Education and Research. 2014; 4(2): 189.

[47] Ayyash H, Aljeesh Y. Nurses' Motivation and their Performance at European Gaza Hospital in Gaza Strip. Journal of Al Azhar University-Gaza (Natural Sciences). 2011; 13: 55-68. 